\title{
Contribution to Globularia phylogeny based on nuclear ribosomal spacer and two chloroplast DNA regions
}

\author{
K. HAZLER PILEPIĆ ${ }^{1}$ \\ M. FRIŠČIĆ 1 \\ A. DURAN ${ }^{2}$ \\ S. MASLO 3 \\ R. GARIĆ 4 \\ S. ČULJAK ${ }^{1}$ \\ K. ŠUTALO ${ }^{1}$ \\ ${ }^{1}$ Department of Pharmaceutical Botany \\ Faculty of Pharmacy and Biochemistry \\ University of Zagreb \\ Schrottova 39, 10000 Zagreb, Croatia \\ ${ }^{2}$ Department of Biology \\ Faculty of Science \\ Selçuk University \\ 42075 Selçuklu, Konya, Turkey \\ ${ }^{3}$ Lundåkerskolan \\ Södra Storgatan 45, 33233 Gislaved, Sweden \\ ${ }^{4}$ Institute for Marine and Coastal Research \\ University of Dubrovnik \\ Kneza Damjana Jude 12, 20000 Dubrovnik, Croatia
}

\section{Correspondence:}

Kroata Hazler Pilepić

Department of Pharmaceutical Botany

Faculty of Pharmacy and Biochemistry

University of Zagreb

Schrottova 39, 10000 Zagreb, Croatia

E-mail:khazler@pharma.hr

Keywords: Globularia, ITS, trnL-trnF, rbcL, Maximum Parsimony, Quaternary

Received January 07, 2016.

Revised June 23, 2016.

Accepted September 01, 2016.

\begin{abstract}
Background and Purpose: Molecular approach has a major impact on phylogenetic studies of plants, considering that it gives useful information about evolutionary events and relations on all taxonomic levels. The sequence data of the nuclear ITS and of two chloroplast regions, $\operatorname{trn} L-\operatorname{trn} F$ spacer and $\mathrm{rbc} L$ gene, obtained from thirteen Globularia L. taxa, including five Anatolian endemics, representing six sections altogether, were analyzed in order to determine the relations between the European and the Anatolian species and get a better insight into the phylogeny of several closely related Globularia taxa.
\end{abstract}

Materials and Methods: Total cellular DNA was extracted from fresh or frozen leaf tissue of thirteen Globularia samples. The ITS regions of nuclear DNA and two chloroplast DNA regions were amplified and sequenced. Obtained nuclear and combined plastid data matrices were subjected to Maximum Parsimony analyses.

Results and Conclusions: Molecular data that were obtained in this study indicate the existence of separate centers of diversification for the European and the Anatolian Globularia. The results provide support for relationships among the studied Anatolian endemic species and indications for a redefinition of affinities of some of the European species. The results presented herein are discussed along with available morphological, karyological, phytogeographical and molecular data.

\section{INTRODUCTION}

Gobularia L. is a small Angiosperm genus mostly comprised of ev$\boldsymbol{J}$ ergreen perennials and small shrubs, recognizable by blue flowers assembled in globular capitula, which it was named after. The first extensive classifications of Globularia were proposed by Schwarz $(1,2)$. They comprised 22-25 taxa, which were divided into nine sections. Subsequently, Schwarz's studies regarding this genus have undergone some modifications by several authors $(3,4,5)$. The finally accepted classification of Globularia separates the genus into eight sections based on morphological characters, cytological data, ecology and distribution. These include Lytanthus, Polycephalium, Carradoria, Hellenion, Globularia, Alypum, Empetron and Gymnocladium (5).

Since most of the taxa are localized in Central and Southern Europe, Anatolia, Northern Africa and Macaronesia, the Mediterranean basin is viewed as their primary center of diversification, which has started approximately 7.57 million years ago in the Miocene $(6,7)$. Globularia vulgaris $\mathrm{L}$. is the only taxon distributed more northward, reaching the 
Baltic region. A total of 15 Globularia species are included in the European flora (8) and 11 taxa in the flora of Turkey $(9,10)$. Among and above these taxa there is a considerable number of endemic species, particularly in Macaronesia (11), Morocco (12), Italy (13), Greece (14) and Turkey $(9,15)$. Taxa of Globularia are known as outcrossing and mainly exhibit two ploidy levels, diploids $(2 n=2 x=16$ chromosomes) and tetraploids $(2 n=4 x=32)$, whereby autopolyploidy is a proposed mode of genome duplication $(1,3,4,16)$. Cytogeographical relations indicate that endemic taxa and taxa which grow in moderate climate areas are predominantly diploids, while taxa with broader distributions and growing in rigorous habitat conditions are mainly tetraploids $(1,3)$. All Globularia examined by now have the same pollen morphology (17). From an economic point of view, several Globularia species are valuable herbal plants, for example G. alypum L. and G. trichosantha Fisch \& C.A. Mey., used in traditional medicine of countries such as Spain, Italy, Tunisia and Turkey $(18,19,20)$. Several recent investigations showed that some widespread European taxa also exhibit medicinal potential $(21,22)$.

In the past few decades, molecular studies have greatly contributed to a better understanding of relations and plant phylogeny at all taxonomic levels. Accordingly, the genus Globularia that had traditionally been included in the homonymous family of Globulariaceae, was meanwhile proposed for inclusion into the Plantaginaceae, based on molecular evidence (23, 24). Moreover, the ITS molecular data obtained from 23 Globularia taxa proposed interesting conclusions about their Miocene origin and Pleistocene independent development of three European Alpine/montane and two Mediterranean Globularia lineages with proposed rate of 0.33 net speciation events per million years $(6,7,25,26)$.

In order to provide better understanding of intrageneric relationships among Globularia, Maximum Parsimony analyses were conducted on three DNA regions from seven European, five Anatolian and one Mediterranean Globularia taxon. Taking into account the above mentioned studies that comprise most of the Globularia species, including Macaronesian endemic species, our study is focused on the comparison of several European and Anatolian species, among which five are endemics. Phylogenetic relationships were reconstructed using the internal transcribed spacer (ITS) of the nuclear rDNA repeats and two chloroplast regions, nontranscribed trnL$t r n \mathrm{~F}$ spacer and plastid gene $r b c \mathrm{~L}$.

\section{MATERIALS AND METHODS}

\section{Plant Material and DNA Extraction}

Samples of 13 Globularia taxa belonging to six sections were studied. The plants were collected from their natural habitats or obtained from botanical gardens. Voucher specimens were deposited in the Herbarium of the Department of Pharmaceutical Botany, Faculty of
Pharmacy and Biochemistry, University of Zagreb, Croatia. Table 1 lists all the data about plant samples, including the geographical distribution of investigated taxa and GenBank accession numbers of the analyzed sequences. Total cellular DNA was extracted from 100$140 \mathrm{~g}$ dry, fresh or frozen leaf tissue following the procedure of Doyle and Doyle (27), modified as reported in Petit et al (28).

\section{Amplification and Sequencing}

The ITS regions of nuclear DNA and two chloroplast DNA regions were amplified via the polymerase chain reaction (PCR) using the primer pairs designed by White et al. (29) for ITS, Taberlet et al. (30) for $\operatorname{trn} \mathrm{L}-\operatorname{trn} \mathrm{F}$ and Hasebe et al. (31) for $r b c \mathrm{~L}$. Amplification reactions were performed in volumes of $50 \mu \mathrm{L}$ containing $0.5 \mu \mathrm{M}$ of each primer, $200 \mu \mathrm{M}$ of each nucleotide, $2 \mathrm{mM} \mathrm{MgCl}_{2}$ and 1.25 units of TaKaRa Taq HS polymerase (Takara Bio Inc, Japan). Amplifications were performed using a Biorad MyCycler 1065 under the following conditions: first denaturation at $93^{\circ} \mathrm{C}$ for $3 \mathrm{~min}$, followed by 35 cycles of template denaturation at $93^{\circ} \mathrm{C}$ for $1 \mathrm{~min}$, primer annealing at $50^{\circ} \mathrm{C}$ for $1 \mathrm{~min}$, elongation at $72^{\circ} \mathrm{C}$ for $1 \mathrm{~min}$ and a final extension at $72^{\circ} \mathrm{C}$ for $10 \mathrm{~min}$. The PCR products were verified by electrophoresis on $0.7 \%$ agarose gels containing ethidium bromide in Tris-acetate EDTA (TAE) buffer and detected under UV light. The size of fragments was estimated by comparison with a molecular size standard (GeneRuler ${ }^{\mathrm{TM}}$ DNA Ladder Mix, Fermentas). The PCR products were purified by using the GFX PCR DNA and Gel Band Purification Kit (GE Healthcare, USA) in accordance with the protocol of the manufacturer. DNA sequencing was performed by Macrogen (Seoul, South Korea) on an ABI3730XL DNA sequencer, using the same primer set as for PCR. Double-stranded sequencing was performed for at least $75 \%$ of their total length. All sequences have been deposited in the GenBank Sequence Database (Table 1).

\section{Sequence Alignment and Phylogenetic Reconstruction}

Nucleotide sequence fragments were manually edited and aligned using ClustalX.2.1 (32). The alignment is available from the author upon request. The data set contained a total of 13 Globularia taxa sequenced in this work, and the sequences of Plantago major L. (trn L-trnF, $r b c \mathrm{~L}$ ), P. lanceolata L. (ITS), Veronica officinalis L. (ITS,

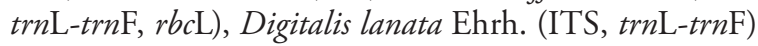
and D. lutea L. $(r b c \mathrm{~L})$, which were retrieved from GenBank. GenBank accession numbers of outgroup taxa are listed in Table 2. We analyzed the nuclear and combined plastid data sets independently and thus two sequence data matrices were generated: (1) an ITS data matrix and (2) a $\operatorname{trn} \mathrm{L}-t r n \mathrm{~F}$ combined with a $r b c \mathrm{~L}$ data matrix, all comprised of 13 Globularia taxa and 3 outgroup taxa.

Sequence data matrices were subjected to phylogenetic analyses using the Maximum Parsimony Method in 
TABLE 1 Plant material, voucher information, geographical distribution and GenBank accession numbers.

\begin{tabular}{|c|c|c|c|c|c|}
\hline Taxon & $\begin{array}{l}\text { Source of } \\
\text { material }^{1)}\end{array}$ & $\begin{array}{l}\text { Voucher } \\
\text { number }\end{array}$ & $\begin{array}{l}\text { Geographical } \\
\text { distribution }{ }^{2)}\end{array}$ & $\begin{array}{c}\text { GenBank } \\
\text { accession number }\end{array}$ & Section $^{4)}$ \\
\hline Globularia alypum L. & $42^{\circ} 30^{\prime} \mathrm{N} 18^{\circ} 19^{\prime} \mathrm{E}, 1$ & 16025_1 & Mediterranean & $\begin{array}{l}\text { ITS KP278477 } \\
\text { LF }^{3)} \text { KT853048 } \\
r b c \text { LT K53061 }\end{array}$ & Alypum \\
\hline $\begin{array}{l}\text { G. anatolica Duran, } \\
\text { Çetin, Öztürk }\end{array}$ & $37^{\circ} 44^{\prime} \mathrm{N} 29^{\circ} 20^{\prime} \mathrm{E}, 2$ & 16030_1 & $\begin{array}{l}\text { Anatolia } \\
\text { endemic }\end{array}$ & $\begin{array}{c}\text { ITS KT757362 } \\
\text { LF KT853049 } \\
r b c \text { L KT853062 }\end{array}$ & Polycephalium \\
\hline G. cordifolia $\mathrm{L}$. & $44^{\circ} 43^{\prime} \mathrm{N} 14^{\circ} 58^{\prime} \mathrm{E}, 3$ & 16035_1 & Central / SE Europe & $\begin{array}{c}\text { ITS KP278478 } \\
\text { LF KT853050 } \\
\text { rbcL KT853063 }\end{array}$ & Empetron \\
\hline G. davisiana O. Schwarz & $36^{\circ} 44^{\prime} \mathrm{N} 30^{\circ} 32^{\prime} \mathrm{E}, 2$ & 16040_1 & $\begin{array}{l}\text { Anatolia } \\
\text { endemic }\end{array}$ & $\begin{array}{c}\text { ITS KT757363 } \\
\text { LF KT853051 } \\
\text { rbcL KT853064 }\end{array}$ & Polycephalium \\
\hline G. dumulosa O. Schwarz & $\mathrm{mc}, 4$ & $16042 \_1$ & $\begin{array}{l}\text { Anatolia } \\
\text { endemic }\end{array}$ & $\begin{array}{c}\text { ITS KT757364 } \\
\text { LF KT853052 } \\
r b c \text { L KT853065 }\end{array}$ & Hellenion \\
\hline G. hedgei H. Duman & $37^{\circ} 27^{\prime} \mathrm{N} 30^{\circ} 54^{\prime} \mathrm{E}, 2$ & 16043_1 & $\begin{array}{l}\text { Anatolia } \\
\text { endemic }\end{array}$ & $\begin{array}{c}\text { ITS KT757365 } \\
\text { LF KT853053 } \\
\text { rbcL KT853066 }\end{array}$ & Polycephalium \\
\hline $\begin{array}{l}\text { G. meridionalis (Podp.) O. } \\
\text { Schwarz }\end{array}$ & $45^{\circ} 22^{\prime} \mathrm{N} 14^{\circ} 30^{\prime} \mathrm{E}, 3$ & $16045 \_1$ & Central / SE Europe & $\begin{array}{c}\text { ITS KP278479 } \\
\text { LF KT853054 } \\
\text { rbcL KT853067 }\end{array}$ & Empetron \\
\hline G. nudicaulis L. & $45^{\circ} 45^{\prime} \mathrm{N} 10^{\circ} 36^{\prime} \mathrm{E}, 5$ & 16050_1 & Central Europe & $\begin{array}{c}\text { ITS KT757366 } \\
\text { LF KT853055 } \\
r b c \text { L KT853068 }\end{array}$ & Gymnocladium \\
\hline G. punctata Lapeyr. & $45^{\circ} 22^{\prime} \mathrm{N} 14^{\circ} 30^{\prime} \mathrm{E}, 3$ & 16059_1 & Europe & $\begin{array}{c}\text { ITS KP278480 } \\
\text { LF KT853056 } \\
r b c \text { L KT853069 }\end{array}$ & Globularia \\
\hline G. repens Lam. & $\mathrm{mc}, 5$ & 16060_1 & SW Europe & $\begin{array}{c}\text { ITS KT757367 } \\
\text { LF KT853057 } \\
r b c \text { L KT853070 }\end{array}$ & Empetron \\
\hline $\begin{array}{l}\text { G. sintenisii Hausskn. \& } \\
\text { Wettst. }\end{array}$ & $37^{\circ} 42^{\prime} \mathrm{N} 41^{\circ} 24^{\prime} \mathrm{E}, 2$ & 16065_1 & $\begin{array}{l}\text { Anatolia } \\
\text { endemic }\end{array}$ & $\begin{array}{c}\text { ITS KT757368 } \\
\text { LF KT853058 } \\
\text { rbcL KT853071 }\end{array}$ & Polycephalium \\
\hline $\begin{array}{l}\text { G. trichosantha Fisch. \& } \\
\text { C.A.Mey. }\end{array}$ & $\mathrm{mc}, 6$ & 16070_1 & E Europe, Anatolia, Crimea & $\begin{array}{c}\text { ITS KT757369 } \\
\text { LF KT853059 } \\
r b c \text { L KT853072 }\end{array}$ & Globularia \\
\hline G. vulgaris $\mathrm{L}$. & $56^{\circ} 58^{\prime} \mathrm{N} 16^{\circ} 46^{\prime} \mathrm{E}, 7$ & 16072_1 & N Iberia, NW Baltic & $\begin{array}{c}\text { ITS KT757370 } \\
\text { LF KT853060 } \\
\text { rbcL KT853073 }\end{array}$ & Globularia \\
\hline
\end{tabular}

1) 1 - Collected by R. Garić from natural stands in Croatia, 2 - Collected by A. Duran from natural stands in Turkey, 3 - Collected by K. Hazler Pilepić from natural stands in Croatia, 4 - Botanische Gärten der Christian-Albrechts-Universität zu Kiel, Germany; 5 - Botanische Gärten der Universität Bonn, Germany; 6 - Botanische Gärten der Philipps-Universität, Marburg, Germany; 7 - Collected by S. Maslo from natural stands in Sweden. mc - missing coordinates. ${ }^{2)}$ Tutin et al (3); Duran et al (9); Schwarz (1); Duman (15); Wettstein (40).. LF - trnL-trnF intergenic spacer. ${ }^{4)}$ Schwarz (1); Duman (15); Duran et al (9).

MEGA 6 (33). Three outgroups were used to root the trees. Phylogenetic reconstructions were carried out via heuristic searches using the Subtree-Pruning-Regrafting (SPR) algorithm (34) with search level 1 in which the initial trees were obtained by random addition of sequences (10 replicates). Gaps and missing data were excluded from the dataset. The bootstrap method (35) was employed to examine the robustness of various clades revealed in the trees.

\section{RESULTS}

\section{Analysis of the ITS Data Set}

The aligned length of the ITS data set was 863 base pairs, 468 of which were constant, while 255 were variable characters and $111(13 \%)$ were potentially parsimonyinformative characters. Six equally parsimonious trees (consistency index 0.763 , retention index 0.794 ) were 
TABLE 2 Outgroup samples' sequences retrieved from GenBank.

\begin{tabular}{|c|c|c|}
\hline Taxon & Sequence & $\begin{array}{c}\text { Accesion } \\
\text { number }\end{array}$ \\
\hline $\begin{array}{l}\text { Plantago lanceolata } \mathrm{L} \text {. } \\
\text { P. major } \mathrm{L} . \\
\text { P. major } \mathrm{L} .\end{array}$ & $\begin{array}{l}\text { ITS } \\
\text { trnL-trnF } \\
r b c \mathrm{~L}\end{array}$ & $\begin{array}{c}\text { AY101898.1 } \\
\text { FJ490807.1 } \\
\text { KF602240.1 }\end{array}$ \\
\hline $\begin{array}{l}\text { Veronica officinalis } \mathrm{L} \text {. } \\
\text { V. officinalis } \mathrm{L} \text {. } \\
\text { V. officinalis } \mathrm{L} \text {. }\end{array}$ & $\begin{array}{l}\text { ITS } \\
\text { trnL-trnF } \\
r b c \mathrm{~L}\end{array}$ & $\begin{array}{c}\text { DQ534900.1 } \\
\text { AF486391.1 } \\
\text { HQ590322.1 }\end{array}$ \\
\hline $\begin{array}{l}\text { Digitalis lanata L. } \\
\text { D. lanata L. } \\
\text { D. lutea L. }\end{array}$ & $\begin{array}{c}\text { ITS } \\
\text { trnL-trnF } \\
r b c \mathrm{~L}\end{array}$ & $\begin{array}{c}\text { AY591284.1 } \\
\text { AY591318.1 } \\
\text { FM207428.1 }\end{array}$ \\
\hline
\end{tabular}

found by Maximum Parsimony analysis of the ITS region of the 13 taxa studied. The $50 \%$ consensus tree is presented in Figure 1. Branches corresponding to partitions reproduced in less than $50 \%$ of the trees were collapsed.

The topology of the ITS consensus tree indicates that Globularia is separated into two major clades with high bootstrap support ( $\mathrm{BS}=83 \% / 83 \%)$. Within clade I a sister relationship between all the European taxa is apparent, while within clade II all the Anatolian taxa are clustered together with the Mediterranean taxon $G$. alypum. The taxa within the European clade are separated into two well-supported subclades (BS $=100 \%)$. The first subclade comprises representatives of the section Globularia along with one from the section Gymnocladium, while all taxa in the second subclade belong to the section Empetron. In the Anatolian clade, the taxa from sections Polycephalium and Alypum form a subclade (BS $=66 \%$ ) divided into two branches (BS $=66 \%$ and $50 \%$ ), while $G$. dumulosa is supported as a sister to this alliance ( $\mathrm{BS}=83 \%$ ).

\section{Analysis of Combined trnL-trnF and rbcL Data Set}

The final alignment of the combined $\operatorname{trn} \mathrm{L}-\operatorname{trn} \mathrm{F}$ and $r b c \mathrm{~L}$ data sets had 2217 positions, 1659 of which were constant, while 501 characters were variable and 81 characters (4\%) were potentially parsimony-informative. Maximum Parsimony analysis of the combined $t r n \mathrm{~L}-\operatorname{tr} n \mathrm{~F}$ and $r b c \mathrm{~L}$ regions of the 16 taxa found two most parsimonious trees (consistency index 0.809, retention index $0.827)$. The $50 \%$ majority rule consensus tree is shown in Figure 2 .

The main topology of the consensus tree produced from combined $t r n \mathrm{~L}-t r n \mathrm{~F} / r b c \mathrm{~L}$ sequence data was not much different from that of the ITS consensus tree. However, lower resolution was noticed for some taxa in the plastid sequences-based tree. All Globularia taxa were grouped into two major clusters. The extensive one (BS = $100 \%)$ comprises all European taxa along with the Anatolian G. dumulosa, while the Mediterranean G. alypum forms a weakly supported sister clade (BS $=50 \%$ ). The second clade contains three representatives from the Anatolian section Polycephalium (BS $=100 \%$ ), while G. sintenisii is separated without support.

\section{DISCUSSION}

The ITS sequence data, which are widely used for phylogenetic reconstruction of closely related species, showed an appropriate level of variation in the genus Globularia. Applied cpDNA regions were found to be less informative for this genus. Slower evolutionary rates of chloroplast genome may cause difficulties in finding the appropriate phylogenetic signal in some plant taxa (36).

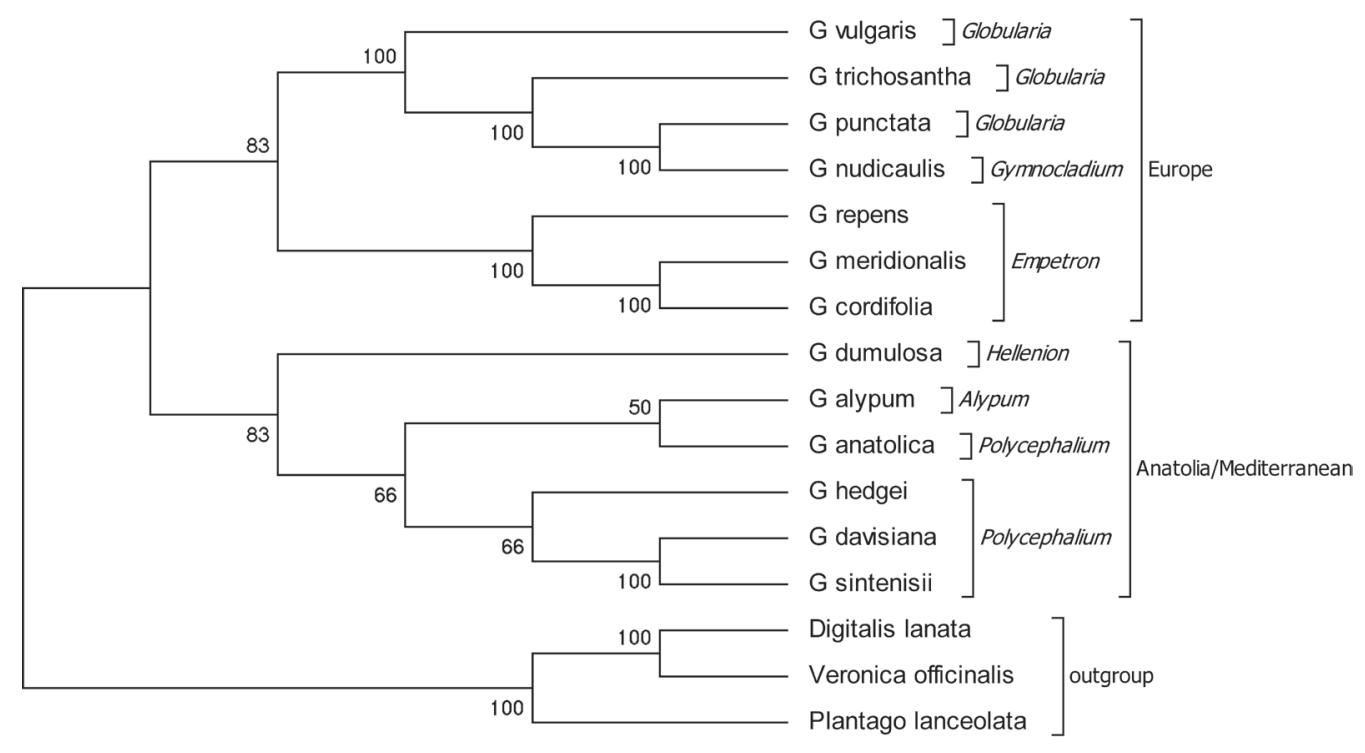

Figure 1. The 50\% consensus tree of 6 most parsimonious trees $(C I=0.763 ; R I=0.794)$ from the Maximum Parsimony analysis of nrDNA ITS sequences obtained from Globularia taxa. Numbers above the branches are bootstrap values. Brackets indicate sections discussed in the text. 
Nevertheless, both trees showed similar topology and several resulting conclusions were derived.

The genus Globularia in this paper is represented by 13 taxa. Seven of them originate from Europe, five are Anatolian, while one is a Mediterranean species. The taxa investigated in our study belong to six sections and the resulting parsimony analysis mainly corroborates the current classification and interspecific affinities. The results of our analyses provide strong evidence for an early split within the genus and further diversification of two lineages in both the European and the Anatolian area.

According to the ITS 50\% consensus tree, G. vulgaris, $G$. punctata and G. trichosantha, representatives of the section Globularia in our data set, form a well-supported clade (BS $=100 \%$ ) including the $G$. nudicaulis, the single representative of the section Gymnocladium. By contrast, the cpDNA tree shows two well supported dichotomous nodes (BS $=100 \%$ ), the first consisted of G. vulgaris and $G$. punctata, while the other one includes $G$. nudicaulis and $G$. trichosantha. The aforementioned taxa are evergreen perennials: G. vulgaris, G. punctata and G. nudicaulis form pleiocormous rosettes, while $G$. trichosantha develops stolons and has an espalier like growth form (5). G. vulgaris is a tetraploid $(1,3,13,16)$ showing two disjunct distribution areas, one on the Iberian peninsula and in Southern France, and the other on the Baltic islands of Öland and Gotland (8). This could indicate that G. vulgaris used to be more widespread than it is today. With respect to the estimated origin of Globularia in the Late Miocene (7), it is possible that these populations separated during the Quaternary and that the polyploidization occured due to unfavorable conditions of glaciation periods. It has been proven that effective $2 \mathrm{n}$ gametes, which may lead to polyploidization, are induced by abiotic stress such as temperature (37). Interestingly, no morphological difference has been noticed between the separated populations (16). G. vulgaris shares a common cpDNA haplotype with $G$. punctata, which is a diploid taxon (1, 3, 5, 16) and the most widespread European Globularia, suggesting the possibility of a common maternal ancestor and overlapping areas in the past. Nevertheless, the ITS data indicates a close relationship of $G$. punctata with $G$. nudicaulis, a montane European taxon distributed in the Alps, the Pyrenees and mountains of Northern Spain. This diploid taxon, which shows great uniformity throughout the geographical range of its distribution (from Northern Spain to the Alps, 8,13 ), belongs to the section Gymnocladium, along with two taxa: G. gracilis Rouy et Richt., which is restricted to the Pyrenees and G. liouvillei Jah. et Maire, an endemic taxon of High Atlas in Morocco. According to Schwarz (1), affiliation to the section Gymnocladium is based on the development of short stolons. However, G. nudicaulis was found to grow without stolons (5). Whereas earlier obtained ITS data (26) have put $G$. nudicaulis in a separate clade along with G. gracilis from the same section, the results of our ITS analysis that indicate a sister-relationship between $G$. nudicaulis and G. punctata are somewhat unexpected. Moreover, in the cpDNA tree, $G$. nudicaulis was positioned with $G$. trichosantha, another member of the section Globularia. These results may be a consequence of incomplete taxon sampling. G. trichosantha is a diploid taxon distributed from the Eastern Balkans to the Crimea. Comes and Kadereit (26) have considered this species an early branching taxon of the Asia Minor clade together with G. punctata, but our molecular data clearly support separation of these European samples from those of Asia Minor.

The position of three taxa in our study that belong to the European section of Empetron (G. cordifolia, G. meridionalis and $G$. repens) was in good agreement with the current intrageneric classification. Close relationship was confirmed by both of our trees $(\mathrm{BS}=100)$. These taxa are morphologically very similar dwarf shrubs, distributed in mountainous regions. $G$. repens is a diploid taxon $(1,3)$, slightly smaller than the other two, commonly found in mountainous regions of South-Western Europe. Comes and Kadereit $(25,26)$, proposed that $G$. cordifolia and $G$. repens, along with other Apennines/Balkan Globularia taxa (G. neapolitana O. Schwarz and G. stygia Orph. ex Boiss.), originated in the Pleistocene. Origin of many montane taxa could be explained by the ecological niche concept.

G. cordifolia and G. meridionalis form a supported (BS $=100)$ subcluster indicating their common ancestor and encouraging existing debates about their taxonomic affiliation. These two taxa are widespread in the mountains of Central and Southern Europe, from the Pyrenees to the Carpathians and show high degree of morphological and karyological polymorphism $(2 \mathrm{n}=16$ or $32,4,16,38$, 39). In his early work, Wettstein (40) had noticed the existence of an intermediate form between these two taxa (G. cordifolia var. intermedia). In spite of that, Schwarz (2) persisted in the division of these taxa, giving distinguishing features and precise geographical distribution for each taxon. Nonetheless, a further comprehensive comparison of these two Globularia throughout their distribution area confirmed a high level of variability (38). Therefore, differentiation based on their morphological features, clearly described by Schwarz, is not always possible, as both of the taxa display mixed characteristics finally leading to their questionable separation $(4,38)$. Even though our results indicate common genealogy, at this level of research it could not be assessed with certainty whether the taxa should be divided or considered as one. Molecular data could suggest that $G$. cordifolia and $G$. meridionalis are evolutionary young, sympatric taxa, among which total reproductive isolation cannot be confirmed, especially taking into account their mixed characteristics, particularly seen in the populations from overlapping areas, such as the Dinaric Alps $(38,41)$. Tetraploid forms, which are mostly found in the Apennines and in the Dinaric regions, could be an effective way of 


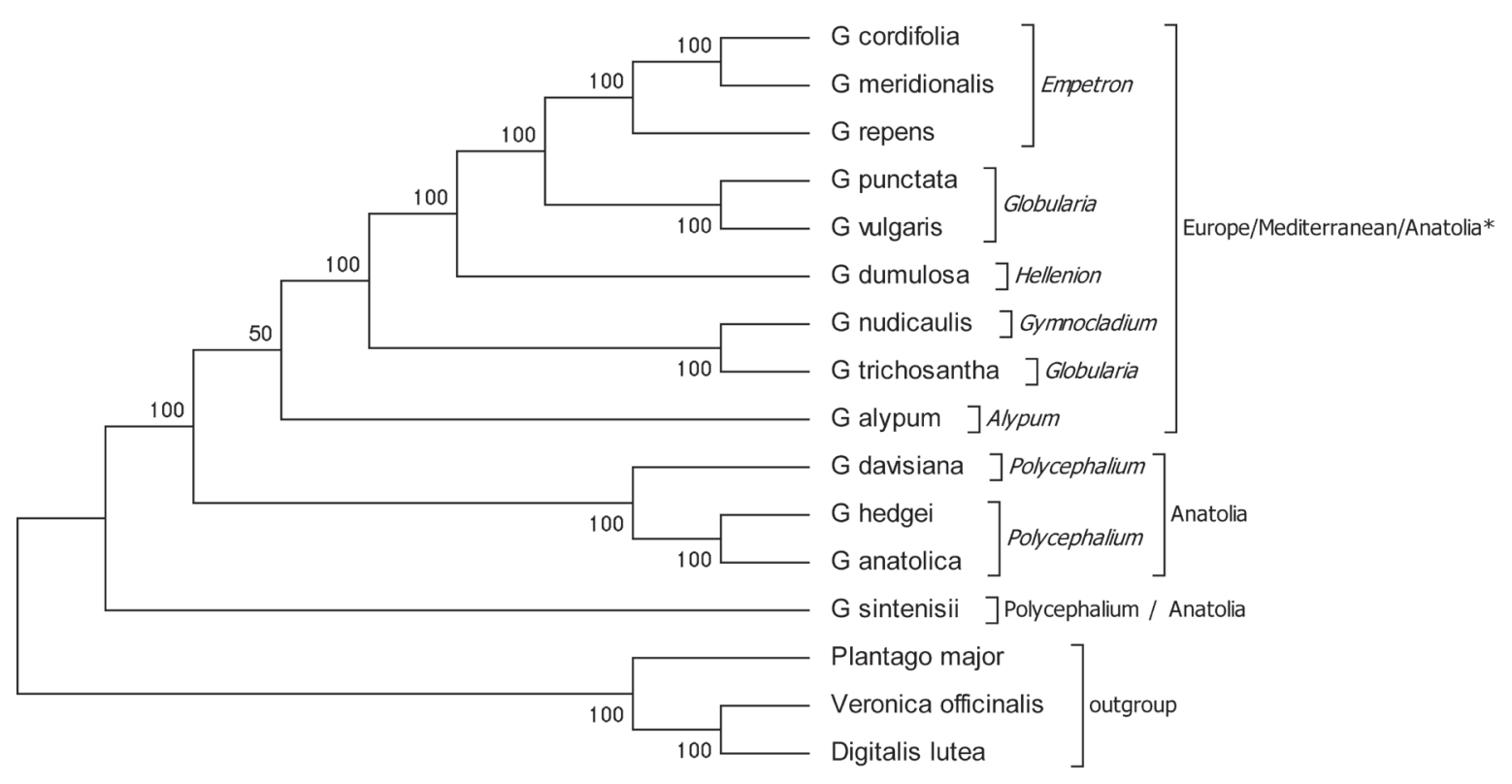

Figure 2. The 50\% consensus tree of 2 most parsimonious trees ( $C I=0.809 ; R I=0.827)$ from the analysis of combined $\operatorname{trn} L$ - $\operatorname{trn} F$ and $\operatorname{rbc} L$ sequences obtained from Globularia taxa. Numbers above the branches are bootstrap values. Brackets indicate sections discussed in the text. ${ }^{*}$ G. dumulosa

adaptation during glaciations and a powerful force for postglacial recolonizations. Existence of a tetraploid form could have some evolutionary advantage, especially in the areas with strong environmental changes (42). However, molecular data that give evidence of close links between G. cordifolia and G. meridionalis could also suggest that these taxa could be considered as one. The results of phytochemical comparative studies of Croatian populations showed a pronounced similarity between their essential oil composition (43) and iridoid content (44). From everything mentioned above, the consideration of these taxa as subspecies, which is very common in older botanical literature, cannot be dismissed $(5,45,46,47$, $48,49,50)$. However, the use of low-copy nuclear genes or some other molecular markers, which could provide sufficient resolution and further evidence on relations among these two taxa, is necessary.

Five Anatolian endemic taxa, G. anatolica, G. davisiana, G. dumulosa, G. hedgei and G. sintenisii, form a clearly resolved clade along with the Mediterranean G. alypum on the ITS tree. Based on the chloroplast sequence data, phylogenetic positions of G. alypum and G. sintenisii were poorly resolved, as demonstrated by weak or no bootstrap support, respectively. According to the same data set, $G$. dumulosa, which belongs to the section Hellenion, was positioned among the European taxa. It is a high-mountainous, long-lived shrub that is morphologically wellcharacterized by hemispherical cushion-forming growth (5). It probably originated in the Pliocene, as did the majority of Globularia (7). Isolated and well-adapted, it remains to be present until today in the area of high mountains.
The remaining investigated Anatolian endemic taxa ( $G$. anatolica, $G$. davisiana, G. hedgei and G. sintenisii) belong to the section Polycephalium. G. anatolica is a new endemic species found recently in the Honaz Mountain National Park (9), an important biogeographical region, very rich in endemic plants. Although this taxon is morphologically most similar to G. sintenisii (9), our ITS data indicate a poorly supported relation with $G$. alypum, which could be a consequence of our incomplete dataset or poor resolution of the ITS alone. By contrast, the cpDNA data confirm its close relation with $G$. hedgei and $G$. davisiana. This result is in accordance with the previous morphological/taxonomic studies which support $G$. anatolica as a member of the section Polycephalium (9). G. hedgei, a local Turkish endemic restricted to a single location in Yazili Kanyon National Park (15), is yet another new species included in our analysis. It is a cushion-forming perennial divided into several rosettes that is morphologically very similar to $G$. orientalis $\mathrm{L}$. and $G$. sintenisii, while it differs from all Globularia species by densely stellate hairs. Molecular data confirm its relation with other Anatolian taxa, G. davisiana and G. sintenisii, and especially with $G$. anatolica on the basis of chloroplast markers. Finally, G. davisiana and $G$. sintenisii are joined together in the ITS tree confirming their similar geographical range and possible origin from a common lineage.

In conclusion, this study indicates existence of separate centers of diversification for European and Asia Minor Globularia. Although Kadereit and Comes (7) proposed that evolutionary events in Globularia dated earlier than the Quaternary, it could be hypothesized that speciation of some of the European and Anatolian taxa began during 
the glacial period, having in mind that morphological characteristics are often under severe ecological selection pressure, which may lead to the creation of advantages necessary for adaptation to extreme habitat conditions. Closely related taxa, such as G. cordifolia and G. meridionalis, as well as the majority of Anatolian endemics, probably developed in such conditions exactly. Nevertheless, conduction of additional research to confirm these assumptions is necessary.

Acknowledgements: The authors would like to thank H. Fulgosi from the Laboratory of Electron Microscopy, Division of Molecular Biology at Ruder Bošković Institute for kindly providing laboratory facilities. The authors are grateful to all institutions that helped with plant material from their collections. This work was supported by the Science and Research Funding of University of Zagreb under Grant 1.1.2.7.

\section{REFERENCES}

1. SCHWARZ O 1963 Chromosomenzahlen, Lebensformen und Evolution der Gattung Globularia L. Drudea 3: 5-16

2. SCHWARZ O 1938 Die Gattung Globularia. Bot Jahrb Syst 69: 318-373

3. CONTANDRIOPOULOS J 1978 Contribution a l'etude cytobiogeographique du genre Globularia. Biologie et écologie méditerranéenne 5: 3-13

4. MILLETTI N 1987 Revisione sistemática del genere Globularia L. (Globulariaceae) in Italia. [dissertation] University of Florence.

5. HOLLÄNDER K, JÄGER EJ 1994 Morphologie, Biologie und ökogeographische Differenzierung von Globularia. Flora 189: 223254

6. KADEREIT JW, GRIEBELER EM, COMES HP 2004 Quaternary diversification in European alpine plants - pattern and process. Philos Trans R Soc Lond B Biol Sci 359: 265 - 274. https:// doi.org/10.1098/rstb.2003.1389

7. KADEREIT JW, COMES HP 2005 The temporal course of alpine plant diversification in the Quaternary. In Bakker FT, Chatrou LW, Gravendeel B, Pelser P (eds). Plant species-level systematics: Patterns, processes and new applications. Regnum Vegetabile 142: $117-130$

8. TUTIN TG 1972 Globularia L. In: Tutin TG, Heywood VH, Burges NA, Moore DM, Valentine DH, Walters SM, Webb DA (eds) Flora Europaea Vol III. Cambridge University Press, Cambridge, p 282

9. DURAN A, ÇETIN Ö, ÖZTÜRK M 2009 Globularia anatolica sp. nov. (Globulariaceae) from the Honaz Mountain National Park, southwest Turkey. Nord J Bot 27: 232-237.

https://doi.org/10.1111/j.1756-1051.2009.00412.x

10. EKIM T 2012 Globularia. In: Güner A, Aslan S, Ekim T, Vural M, Babaç MT (eds) Türkiye Bitkileri Listesi (Damarlı Bitkiler). Nezahat Gökyiğit Botanik Bahçesi ve Flora Araştırmaları Derneği Yayını, İstanbul, p 672

11. BARRENO E, BRAMWELL D, CABEZUDO B, CARDONA MA, COSTA M, FERNÁNDEZ-CASAS FJ et al 1984 Listado de plantas endémicas, raras o amenazadas de España. Información Ambiental 3: 48-71

12. MATEOS MA, VALDÉS B 2006 A new species of Globularia (Globulariaceae) from the Talassemtane National Park, N Morocco. Willdenowia 36: 409-412. https://doi.org/10.3372/wi.36.36137
13. PIGNATTI S 1982 Flora d'Italia Vol. II. Edagricole, Bologna, p 620

14. DIMOPOULOS P, RAUS T, BERGMEIER E, CONSTANTINIDIS T, IATROU G, KOKKINI S et al 2013 Vascular plants of Greece: an annotated checklist. Englera 31: 1-370

15. DUMAN H 2001 A new species of Globularia L. (Globulariaceae) from South Anatolia. Bot J Linn Soc 137: 425-428. https://doi.org/10.1006/boj1.2001.0489

16. LARSEN K 1957 Cytological observation on some species of Globularia. Botaniska notiser 110: 265-270

17. ARGUE CL 1993 Pollen morphology in the Selagineae, Manuleae (Scrophulariaceae), and selected Globulariaceae, and its taxonomic significance. Am J Bot 80: 723-733. https://doi.org/10.2307/2445442

18. SEZIK E, TABATA M, YEŞILADA E, HONDA G, GOTO K, IKESHIRO Y 1991 Traditional medicine in Turkey. I. Folk medicine in northeast Anatolia. J Ethnopharmacol 35: 191-196. https://doi.org/10.1016/0378-8741(91)90072-L

19. LEPORATTI ML, GHEDIRA K 2009 Comparative analysis of medicinal plants used in traditional medicine in Italy and Tunisia. J Ethnobiol Ethnomed 5: 31-38. https://doi.org/10.1186/17464269-5-31

20. CARRIÓ E, VALLÈS J 2012 Ethnobotany of medicinal plants used in Eastern Mallorca (Balearic Islands, Mediterranean Sea). J Ethnopharmacol 141: 1021-1040. https://doi.org/10.1016/j.jep.2012.03.049

21. TUNDIS R, BONESI M, MENICHINI F, LOIZZO MR, CONFORTI F, STATTI G, PIRISI FM, MENICHINI F 2012 Antioxidant and anti-cholinesterase activity of Globularia meridionalis extracts and isolated constituents. Nat Prod Commun 7: 1015-1020

22. SIPAHI H, BECKER K, GOSTNER JM, CHAREHSAZ M, KIRMIZIBEKMEZ H, SCHENNACH H, AYDIN A, FUCHS D 2014 Effects of globularifolin on cell survival, nuclear factor- $\kappa B$ activity, neopterin production, tryptophan breakdown and free radicals in vitro. Fitoterapia 92: 85-92. https://doi.org/10.1016/j.fitote.2013.10.012

23. OXELMAN B, BACKLUND M, BREMER B 1999 Relationships of the Buddlejaceae s. 1. investigated using parsimony jackknife and branch support analysis of chloroplast $n d h \mathrm{~F}$ and $r b c \mathrm{~L}$ sequence data. Syst Bot 24: 164-182. https://doi.org/10.2307/2419547

24. ALBACH DC, MEUDT HM, OXELMAN B 2005 Piecing together the „new“ Plantaginaceae. Am J Bot 92: 297-315. https:// doi.org/10.3732/ajb.92.2.297

25. COMES HP, KADEREIT JW 2001 Tests of Pleistocene speciation among alpine and montane species of Globularia (Globulariaceae) from the European high mountains. Bauhinia 15: 76

26. COMES HP, KADEREIT JW 2003 Spatial and temporal patterns in the evolution of the flora of the European Alpine System. Taxon 52: 451-462. https://doi.org/10.2307/3647445

27. DOYLE JJ, DOYLE JL 1990 Isolation of plant DNA from fresh tissue. Focus 12: 13-15

28. PETIT RJ, KREMER A, WAGNER DB 1993 Geographic structure of chloroplast DNA polymorphisms in European oaks. Theor Appl Genet 87: 122-128. https://doi.org/10.1007/BF00223755

29. WHITE TT, BRUNS T, LEE S, TAYLOR J 1990 Amplification and direct sequencing of fungal ribosomal RNA genes for phylogenetics. In: Innis M, Gelfand D, Sninsky J, White T (eds) PCR Protocols: A Guide to Methods and Applications. Academic Press, California, p 315.

https://doi.org/10.1016/b978-0-12-372180-8.50042-1

30. TABERlet P, GIELly L, PAUTOU G, BOUVET J 1991 Universal primers for amplification of three non-coding regions of chloroplast DNA. Plant Mol Biol 17: 1105-1109. https://doi.org/10.1007/BF00037152 
31. HASEBE M, OMORI T, NAKAZAWA M, SANO T, KATO M, IWATSUKI K $1994 \mathrm{rbcL}$ gene sequences provide evidence for the evolutionary lineages of leptosporangiate ferns. Proc Natl Acad Sci USA 91: 5730-5734

32. LARKIN MA, BLACKSHIELDS G, BROWN NP, CHENNA R, MCGETTIGAN PA, MCWILLIAM H et al 2007 Clustal W and Clustal X version 2.0. Bioinformatics 23: 2947-2948. https://doi.org/10.1093/bioinformatics/btm404

33. TAMURA K, STECHER G, PETERSON D, FILIPSKI A, KUMAR S 2013 MEGA6: Molecular Evolutionary Genetics Analysis version 6.0. Mol Biol Evol 30: 2725-2729. https://doi.org/10.1093/molbev/mst197

34. NEI M, KUMAR S 2000 Molecular Evolution and Phylogenetics. Oxford University Press, New York, p 126

35. FELSENSTEIN J 1985 Confidence limits on phylogenies: An approach using the bootstrap. Evolution 39: 783-791. https://doi.org/10.2307/2408678

36. BORSCH T, QUANDT D 2009 Mutational dynamics and phylogenetic utility of noncoding chloroplast DNA. Plant Sys Evol 282: 169-199. https://doi.org/10.1007/s00606-009-0210-8

37. DE STORME N, GEELEN D 2013 Sexual polyploidization in plants - cytological mechanisms and molecular regulation. New Phytol 198: 670-684. https://doi.org/10.1111/nph.12184

38. RAVNIK V 1965 Zur morphologisch-systematischen und chorologischen Problematik der Art Globularia cordifolia L. s. lat. Razpr Slov Akad Znan Umet Razred Prirodosl 8: 5-41

39. KLIPHUIS E, WIEFFERING JH 1972 Chromosome numbers of some angiosperms from the South of France. Acta Bot Neerl 21: 598-604. https://doi.org/10.1111/j.1438-8677.1972.tb00218.x
40. WETTSTEIN R 1895 Globulariaceen-Studien. Bull Herb Boiss 6: $271-290$

41. LJUBIČIĆ I, BRITVEC M, PLAZIBAT M, VITASOVIĆ KOSIĆ I 2010 Flora of the South-Western part of the National Park „Northern Velebit”. Agric Conspec Sci 75: 67-73

42. PARISOD C, HOLDEREGGER R, BROCHMANN C 2010 Evolutionary consequences of autopolyploidy. New Phytol 186: 5-17. https://doi.org/10.1111/j.1469-8137.2009.03142.x

43. CRKVENČIĆ M, DUDAŠ S, JERKOVIĆ I, MARIJANOVIĆ Z, POLJUHA D, HAZLER PILEPIĆ K 2016 Essential oil composition of three Globularia species. Chem Biodivers 13: 219223.

44. SERTIĆ M, CRKVENČIĆ M, MORNAR A, HAZLER PILEPIĆ K, NIGOVIĆ B, MALEŠ Ž 2015 Analysis of aucubin and catalpol content in different plant parts of four Globularia species. J Appl Bot Food Qual 88: 209-214. http://dx.doi.org/10.5073/JABFQ.2015.088.030

45. FIORI A 1925-1929 Nuova flora analitica d'Italia Vol II. Tipografia di M. Ricci, Firenze, p 474

46. HAYEK A 1927 Prodromus florae peninsulae Balcanicae Vol I. Verlag des Repertoriums, Dahlem, p 400

47. DEGEN A 1938 Flora Velebitica Vol III. Verlag der Ungar, Akademie der Wissenschaften, Budapest, $\mathrm{p} 44$

48. DOMAC R 1973 Mala flora Hrvatske i susjednih područja. Školska knjiga, Zagreb, p 340

49. STOJANOV N, STEFANOV B 1948 Flora na Bălgarija. University Press, Sofia, p 1062

50. NIKOLIĆ T 2000 Index Florae Croaticae Pars III. Nat Croat 9: 46 